\title{
EVALUATION OF HOUSING CONSTRUCTION STRATEGIES IN CHINA USING FUZZY-LOGIC SYSTEM
}

\author{
Yeng-Horng PERNG ${ }^{1}$, Sung-Lin HSUEH ${ }^{1}$ and Min-Ren YAN ${ }^{2}$ \\ 1 Department of Architecture, National Taiwan University of Science and Technology (NTUST), 43, Section \\ 4, Keelung Road, Taipei 106, Taiwan \\ E-mail: Perng@mail.ntust.edu.tw; hsueh.sl@msa.hinet.net \\ 2 Institute of Engineering Science and Technology, National Kaohsiung First University of Science and \\ Technology (NKFUST), 1 University Road, Yuanchau, Kaohsiung 824, Taiwan \\ E-mail: u9015908@ccms.nkfust.edu.tw
}

Received 19 May 2005; accepted 10 July 2005

\begin{abstract}
There is a large demand for and a large profit potential in the Chinese housing market. However, foreign investors still suffer high risk because they are unfamiliar with the complexities of this enormous market. This paper presents the issues associated with housing sales in the People's Republic of China and the applications of Fuzzy Logic and Delphi Method to the prediction of sales performance in China's housing. Furthermore, the study presents the concept of an AND/OR logic gate based model, so that expert knowledge can be converted through computation into the needed rules for decision making related to housing sales performance prediction. The logic gate model is useful for 'if-then' rule analysis, monitoring during the model building and amendment process, and in model maintenance in the later stages of its application. The aim of the described model is to provide a computer-based decision support tool for foreign investors and contractors in evaluating beforehand the business feasibility of entering the Chinese housing market.
\end{abstract}

KEYWORDS: Fuzzy logic; Delphi; If-then rules; Evaluation model; Housing

\section{INTRODUCTION}

The Chinese construction market is currently rated as the most attractive market globally for the next five years [5]. Due to rapid economic growth of China in recent years, urban areas are in great need of public facilities and housing. Based on figures from the $\mathrm{Na}-$ tional Bureau of Statistics of China [10], the added value of the Chinese construction industry rose from $828,224,970,000 \mathrm{RMB}$ in 1996 to $1,536,156,260,000 \mathrm{RMB}$ in 2001 . In addition, the Chinese government has emphasized housing and infrastructure as the two critical sectors in its economic policy for the coming years [15]. As a result, Chinese housing construction has become a hot investment market due to the growing population in urban centers, along with the advantages of low construction cost and high profit. Entering the Chinese construction market, foreign investors can either cooperate with local partners to set up a company or obtain an exclusive project in the form of a business investment and work together with a specified Chinese firm to carry out the project. Making decisions about investments in housing is a complicated issue and it is difficult to quantify the influence of factors such as the attributes related to land, specific building designs, construction plans, customer demand, and many others. Thus, comprehensive and reliable evaluation of these factors combined becomes exceedingly complex.

In addition, roughcast housing construction, or in Chinese "Mao-Pei", is prevalent and the mainstream of Chinese housing design and 
construction practice. The Mao-Pei approach is limited to supplying a wired junction box installation at the entrance to a flat and a water pipe in the kitchen but no other facilities in any other rooms. The walls and floors are left with concrete surface finish. Thus, roughcast housing as supplied to clients does not provide a finished housing unit. The supply chain of roughcast housing, or the so-called two-stage supply chain, is shown in Figure 1. Whether roughcast housing continues to meet the continually climbing standards of Chinese people is worth additional exploration. Besides, customer specified housing products are different from those in public construction [9]. In public construction builders simply need to follow the project owner's specifications and deliver the project as agreed to in the contract. Owner-builder investment in a housing project carries more risk because the decision-maker is uncertain if the build product can meet the market needs at the time when the building under construction is finished. Moreover, Baffoe-Bonnie's study proves that economic variation has direct effects on sales amounts [2]. Therefore, in order to reduce investment risk, a set of objective evaluation models should be established to help decision-making and increase competitiveness [13]. This approach presented here utilizes Fuzzy Logic as an underlying computational approach and the Delphi Method to collect knowledge from real estate professionals, from construction firms and other associated industries in China. The results of this effort are the basis for the creation of a Fuzzy Logic Inference System (FLIS). Using sensitivity analysis with respect to the decision variables identified in this research, FLIS is designed to help in identifying factors affecting sales of residential units and thus improve the efficiency of business decisions of owner-builders. An AND/OR logic gate model is used as the foundation for the decision rule base. The model is intended to convert experts' knowledge into the decision rules for FLIS and facilitate the analysis of the effect of 'IF-THEN' rules upon the modeling process as well as model inspection and maintenance afterwards.

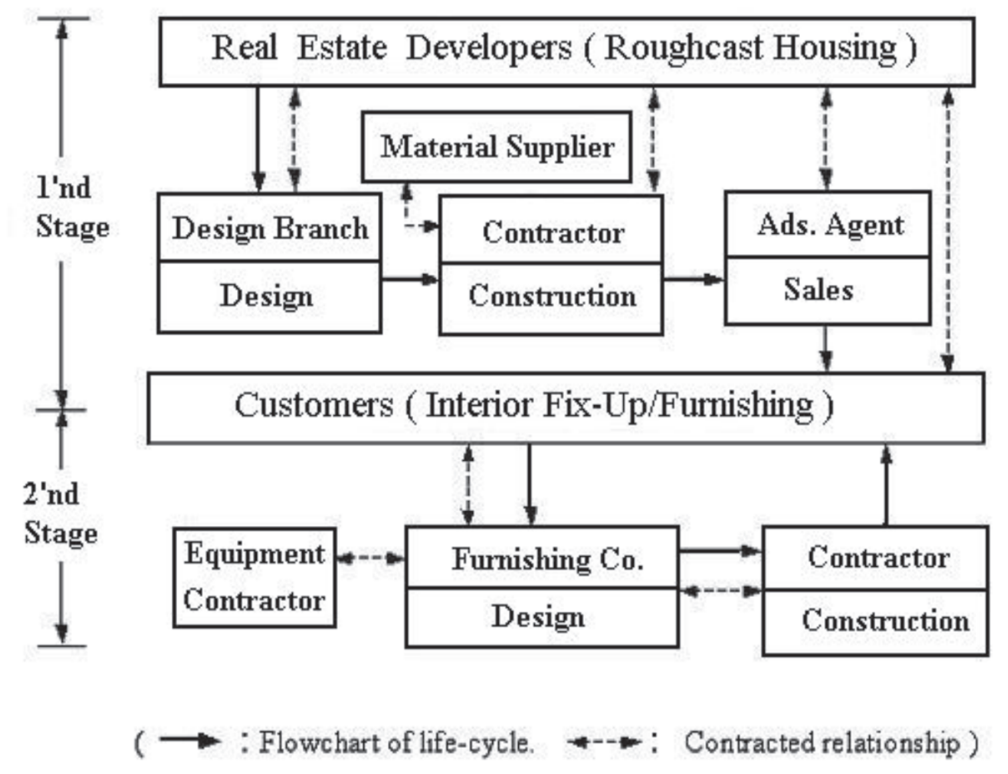

Figure 1. Two Stage Supply Chain of China Roughcast Housing 


\section{FUZZY LOGIC DECISION SYSTEMS FOR SALES-RATIO EVALUATION}

Zadeh first developed fuzzy logic in the 1960 s to represent uncertain and imprecise information [18]. It provides approximate but effective descriptions for highly complex, ill defined, or difficult-to-analyze mathematical systems [8]. Many successful applications of fuzzy set theory have been found in the numerical control of manufacturing processes. Other successful applications in construction include new construction technology evaluation [6], constructability analysis [17] and others.

FLIS consists of four major components [16]: (1) fuzzifier, (2) inference engine, (3) rule base, and (4) defuzzifier. Figure 2 shows a typical structure of FLIS, where $\mathrm{X}$ represents system input and $\mathrm{Y}$ represents system output. $\mathrm{X}$ represents the set of key attributes, which influence the potential sales-ratio. The reasoning process of FLIS begins with the fuzzification of the key attributes. All key input attributes are converted into fuzzy sets. Each fuzzy set consists of linguistic terms and the associated memberships. In Figure 2, (X) represents fuzzy memberships of the linguistic terms describing input attributes after fuzzification. Then, the linguistic terms are matched with the preconditions of fuzzy IFTHEN rules. For any fuzzy IF-THEN rule whose preconditions are satisfied, the fuzzy IFTHEN rule is fired. The last step of FLIS reasoning is defuzzification of consequence terms. For details of FLIS, the reader is referred to [21].

FLIS is not ready for use until the membership functions of input and output linguistic terms and the knowledge base are determined. This study employs the Delphi Method to collect professional information from experts in the housing business in China and to set up fuzzy membership functions along with fuzzy inference rules. Generating improved quality of information; more informed opinions and more correct decision making can be facilitated via opinion polls in an expert group [20]. The expert group in this research included 10 experts (including two chief executive officers): senior executives and managers from construction, real estate, and advertisement/marketing businesses; senior government officials and university professors who have been working as experts in real estate and construction related fields for a minimum period of six years or more.

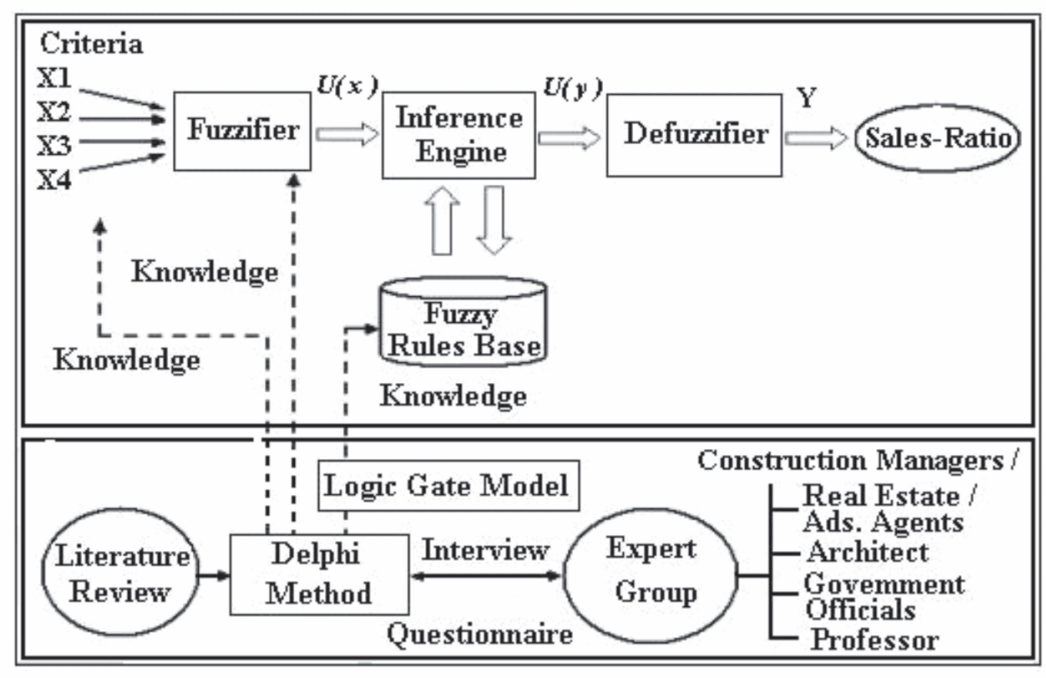

Figure 2. The Proposed FLIS for Sales-Ratio Evaluation 
Our research team worked on information gathering and our questionnaire survey conducted in China during August of 2003 to March of 2004. Figure 2 indicates that expert knowledge was obtained both from various documents made available to the team, and from a questionnaire survey of the various experts. The compiled information was then verified by the expert group. The expert knowledge was compiled as follows: (1) the evaluation criteria used are the result of reconciling the available documents and survey outcomes, subsequently verified by an expert group. (2) Compilation of knowledge obtained in step 1 above to build IF-THEN rules and generate information about the level of success with the sales of the housing units constructed. Opinions of 20 project managers from real estate developer firms along with sales records of historic business cases in housing sales were compiled and verified by a group of experts. This allowed the identification of the sales ratio as the ratio of the total housing units sold to the total number of constructed units.

Figure 2 depicts the structure of FLIS and the main approach used in this study to determine the sales ratio of housing units of interest.

\section{INTRODUCTION OF LOGIC GATE MODEL}

When we-human beings are making judgments, we get used to using words: AND, OR to connect different criteria and then organize simple and effective inferences for evaluation; therefore, this study applies AND/OR logic gates and the theory of logic computing to calculate the implication of professionals' information via Boolean Algebra and gain the IFTHEN rules required by FLIS. Boolean Algebra computation logic is the creation of English mathematician- Boole (1815-1864). In the $1940 \mathrm{~s}$, because of the development of electronic calculators, Boolean Algebra became the foundation for logic circuits. In a Logic Gate, an And Gate logic calculation is represented by “* "; and " + " represents OR Gate logic computation. In Figure 3 you can see the logic computation relationship between input and output of an AND/OR Logic Gate. B1 and B2 are input points and $\mathrm{A}$ is an output point. The relation in between is Boolean Algebra: the AND Gate is $\mathrm{A}=\mathrm{B} 1 * \mathrm{~B} 2$; the OR Gate is $\mathrm{A}=\mathrm{B} 1+\mathrm{B} 2$.

The input and output of Figure 3 is either 0 or 1,0 means LOW; 1 means HIGH. The logic gate computation is the practice of Boolean Algebra. The formulae of the basic principles of Boolean Algebra are:
(1) $\mathbf{A}^{*} \mathbf{A}=\mathbf{A}$
(2) $\mathbf{A}+\mathbf{A}=\mathbf{A}$
(3) $\mathbf{A}+\mathbf{A} * \mathbf{B}=\mathbf{A}$
(4) $\mathrm{A} * 0=0$
(5) $\mathbf{A} * \mathbf{1}=\mathbf{A}$
(6) $0+\mathrm{A}=\mathrm{A}$
(7) $A+1=1$

After comprehending the AND/OR Gate concept, we can use Boolean Algebra to compute the output of Figure 4. If the input of Figure 4 is B,C,B,D and output is A, then:

$$
\begin{aligned}
\mathrm{A} & =\mathrm{A} 1 * \mathrm{~A} 2=(\mathrm{B}+\mathrm{C})(\mathrm{B}+\mathrm{D})= \\
& \mathrm{BB}+\mathrm{BD}+\mathrm{CB}+\mathrm{CD} \\
& =\mathrm{B}(1+\mathrm{D}+\mathrm{C})+\mathrm{CD} \\
& =\mathrm{B}+\mathrm{CD}
\end{aligned}
$$

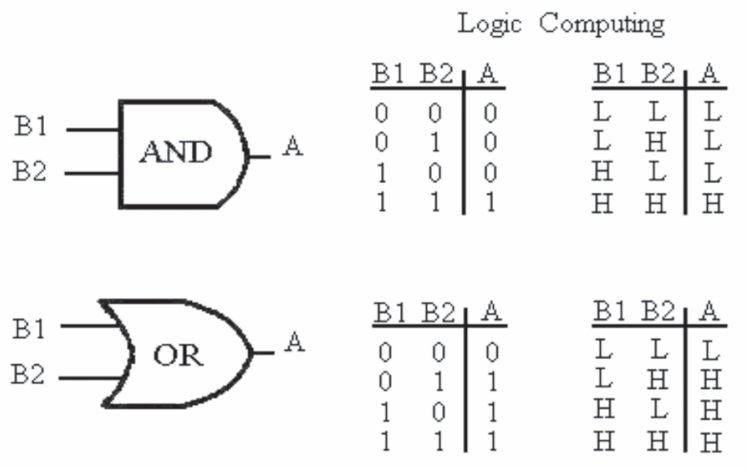

Figure 3. AND Logic Gate and OR Logic Gate

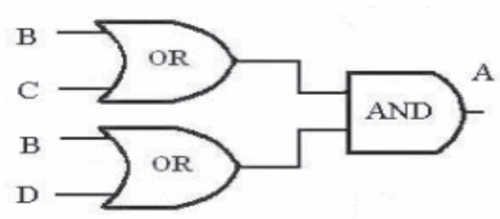

Figure 4. AND/OR Logic Gate 
We can see that the original A combination includes: BB,BD,CB, and CD: 4 Scenarios, and we use Boolean Algebra for simplification, then only B and CD, 2 scenarios are left for A combination set; and $\mathrm{B}, \mathrm{CD}$ is named as the minimum cut set of the A combination.

According to traditional if-then structure (AND/OR operators), each input criterion will have three membership functions if all possible combinations are considered, a total of four criteria will have $3 * 3 * 3 * 3=81$ rules produced. If we use an AND / OR Logic Gate Model, then there will be 81 rules produced. Figure 5 Logic Gate demonstrates an AND / OR Model of four input criteria with three membership functions each, in which we use A, B, C, D to indicate four input criteria; and $\mathrm{AH}, \mathrm{AM}, \mathrm{AL}$ to indicate three membership functions of A criterion, which are: High, Moderate, Low (B, C, D criterion likewise), the Boolean Algebra computation for Output A is as below:

$$
\begin{aligned}
& \text { Output } \mathrm{A}=\left(\mathrm{A}_{\mathrm{H}}+\mathrm{A}_{\mathrm{M}}+\mathrm{A}_{\mathrm{L}}\right) *\left(\mathrm{~B}_{\mathrm{H}}+\mathrm{B}_{\mathrm{M}}+\mathrm{B}_{\mathrm{L}}\right)^{*} \\
& \left(\mathrm{C}_{\mathrm{H}}+\mathrm{C}_{\mathrm{M}}+\mathrm{C}_{\mathrm{L}}\right) *\left(\mathrm{D}_{\mathrm{H}}+\mathrm{D}_{\mathrm{M}}+\mathrm{D}_{\mathrm{L}}\right) \\
& =\mathrm{A}_{\mathrm{H}} \mathrm{B}_{\mathrm{H}} \mathrm{C}_{\mathrm{H}} \mathrm{D}_{\mathrm{H}^{+}}+\mathrm{A}_{\mathrm{H}} \mathrm{B}_{\mathrm{H}} \mathrm{C}_{\mathrm{H}} \mathrm{D}_{\mathrm{M}^{+}} \\
& +\mathrm{A}_{\mathrm{L}} \mathrm{B}_{\mathrm{L}} \mathrm{C}_{\mathrm{L}} \mathrm{D}_{\mathrm{L}}=81
\end{aligned}
$$

Since all the above listed 81 scenarios are different, there is no way to simplify them. Therefore, A combination is the minimum cut set and we map output: High, Moderate or Low for these 81 scenarios under the identified term and get 81 rules, which explains that in fact, the AND/OR Logic Gate Model is the same as the traditional if-then structure (AND/OR operators), but the Logic Gate Model shows more functions for displaying the knowledge implications of rule base and getting the needed IfThen rules for FLIS via computation as well and what's more, it can facilitate beforehand analysis, inspection and amendment together with maintenance afterward.

\section{SELECTION OF INITIAL CRITERIA}

As in most sales scenarios in private business, it is intuitive that the key to achieving a good sales ratio in a housing development project is to put consumers' satisfaction as top priority. Prior studies discussed how to elevate customers' satisfaction in a housing project. Bennett [3], who writes from the customers' point of view, suggests that building plans must emphasize fashionable design. Besides the competitiveness of the plan design, Altas [1] and Ozsoy et al. [14] deemed that due to users' growing concern about the quality of housing and environment, the quality of the region's environment plays an important role in affecting the customers' attraction to a housing project. Ozsoy et al. [14] point out that the housing plan design must place emphasis on the 'coziness' of the external environment so as to raise users' contentment. Ziara and Ayyub

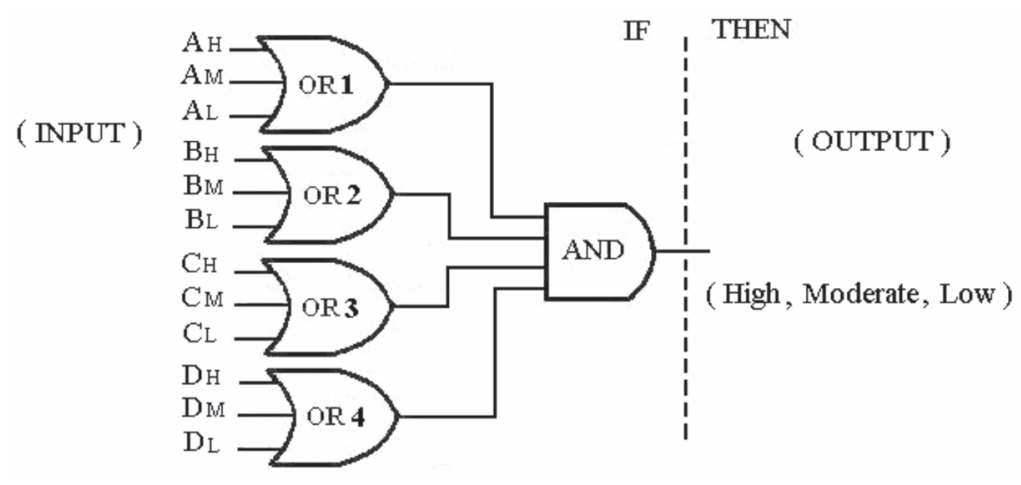

Figure 5. Logic Gate Model's Four Input Criteria with Three Membership Functions 
[19] suggest that housing price reduction can attract consumers with average income and thus increase the mass attraction of a housing project. Based on the above ideas, three criteria, which can satisfy customers' demands and raise satisfaction, are recognized; namely: product offered, quality of the regional environment, and price.

In an earlier period, Grebler [7] investigated the variation of housing prices from 1968 to 1977 in the United States and found out that one of the important factors affecting housing price is the level of earnings of consumers. Nillis and Longbotten [12] also reached the same conclusion in a study of housing prices from 1970 to 1980 in England; the most important factor affecting housing prices being the customers' real disposable income. Baffoe's [2] recent study proved that economic variation has direct effects on sales price and sales amount.

Local partnership criteria should also be taken into firm consideration because in a case of an international firm entering the Chinese construction market; collaboration with local Chinese partner firms is a must. According to Bing et al. [4], risk factors are grouped into three main groups: (1) Internal, (2) Project-specific, (3) External; and sum up twenty-five risk factors for International joint ventures $(J V s)$. Shen et al.'s [15] study of risk factors in Chinese construction JVs states that there are 58 proven risk factors derived from six dimensions, namely: technical risk, management risk, market risk, financial risk, and political risk. The present study compiles these previous reviews to obtain influential factors for use as bases for queries in our questionnaire.

The research team conducted information gathering and surveys in China between December 2002 and August 2003 by means of face-to-face consultations and questionnaires distributed by five Taiwanese project managers engaging in housing construction $\mathrm{JVs}$ in China. A total of 100 questionnaires were handed out and 42 valid responses were received. The respondents included 17 senior construction project managers, 12 real estate developers, 10 advertising/marketing agents and 3 architects with excellent working experience in various $\mathrm{JVs}$ in major cities such as Shanghai, Chungshan, and Chuhai (refer to Figure 6 for the distribution of respondents).

Analyzing the questionnaire answers, there are twelve criteria accepted by over $50 \%$ of the interviewees: product characteristics, regional environment, product price, economic status of potential clients, agreements and contracts, renegotiation capabilities, good business and community relationships, policy, technical skills, competitiveness, subcontractor relations, and employee relations. In order to reduce this list of criteria for greater ease of handling by FLIS, we asked the group of experts to confirm their choices, hoping to simplify the input. Using the Delphi process to accumulate expert opinions, we finished with four important criteria: Design/Regional environment, Price/Competitiveness, Economic Status/Policy, and Agreement/Relationship.

\section{THE FUZZY LOGIC INFERENCE SYSTEM}

Among the two inference systems for fuzzy logic: mamdani and sugeno, the output of mamdani is generally considered successive, while sugeno is scattered. Hoping to discover successive variations of output, we used a mamdani model to set up the Fuzzy Logic In-

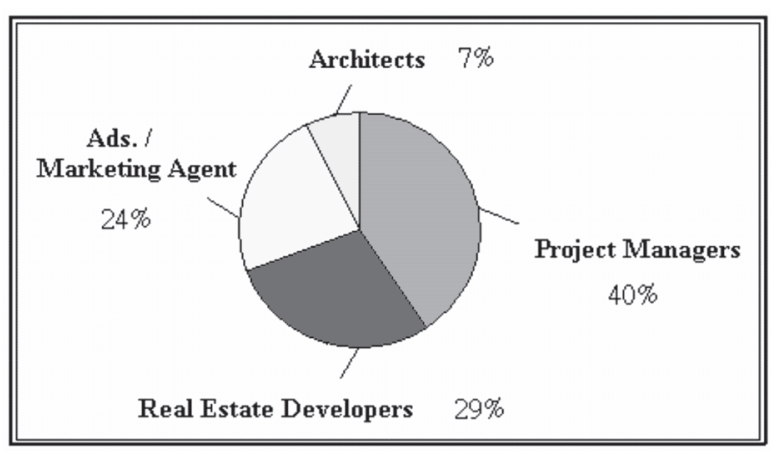

Figure 6. Distribution of Respondents 
ference System and categorize it into four segments: fuzzy set definition of input criterion/ output value; logic gate model of IF-THEN rules; fuzzy scale of membership functions; and defuzzification of output. Descriptions of these segments are as follows.

\subsection{Fuzzy set of Input Criterion/Output value}

Each criterion represents diverse influences on a housing product's attractiveness, thus to determine the evaluation standard it needs an individual fuzzy set for each criterion. Determination of the maximum and minimum levels for four criteria (Design/Regional Environment, Price/competitiveness, Economic status/ policy coherence, and Agreement/relationship) are shown in Table 1. We define the fuzzy scale for Economic status/ policy according to the 'housing alarm index' set by the National Bu- reau of Statistics of China to measure the housing market, which are: 'hot,' 'common' and 'blue' [11]. We contrast the historic 'hot,' 'common' and 'blue' alarm indices with historic economic growth rates of China and obtain the fuzzy scale of Economic status/ policy fuzzy range. As shown in Figure 7, Chinese economic growth rate (GDP) during 1990-2004 was between 0 and 15 , therefore we determine the corresponding fuzzy range for Economic status/policy to be $0-15$, which agrees with BaffoeBonnie's [2] conclusion. In Figure 7, Chinese GDP increase between 1996 and 1997 is close to $10 \%$ annually, yet the housing market index shows 'blue' and 'extremely' blue, which is because of the "Broad Perspective, Conservative Control Policy" which was proclaimed arbitrarily by the Chinese government in 1994 in order to restrain the overheated economy. However, the same policy, executed in 2004, was much more moderate and consequently it

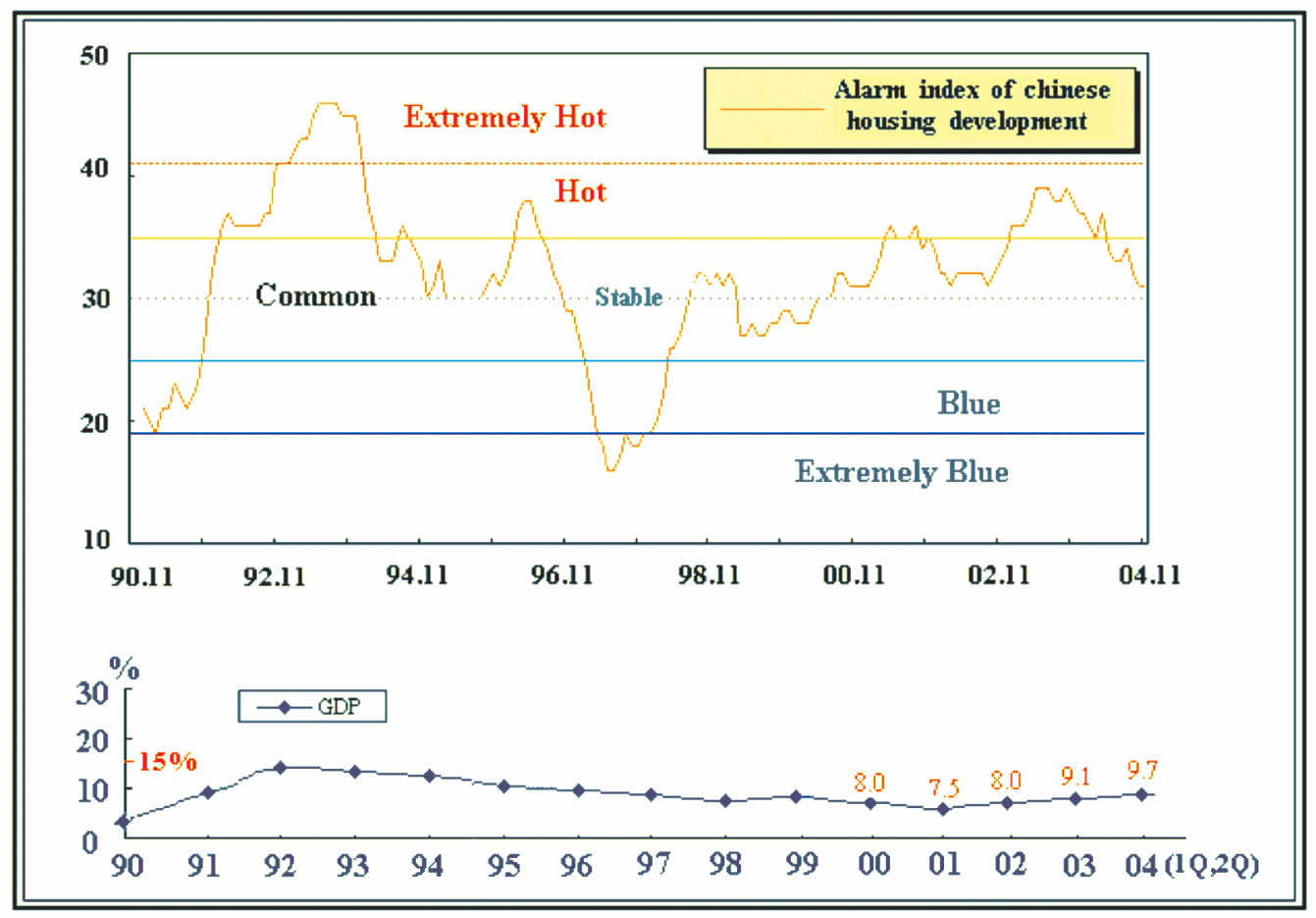

Figure 7. Fuzzy Scale of Economic status/Policy 
caused only a minor impact on the housing market. Therefore, this explains why the 'Economic status' and 'Policy' should both be considered. We determine the fuzzy scale for Economic status/ policy as the following: 'hot' for Chinese GDP increase above 8\%; 'common' for GDP between $5 \%$ - 8\%, and 'blue' for GDP increase below $5 \%$.

Concerning the fuzzy set of sales-ratios, we interviewed management supervisors from 20 real estate developers and ad/marketing agents for sales-ratio statistics of housing products and reached the conclusion that: (1) for formal sales after project completion, if the sales-ratio reaches $80 \%$ in eight months, the housing project will possibly be sold out within one and a half years and gain a good profit as a successful case; (2) If the sales-ratio reaches $50 \%$ in 8 months, the estimated sales revenue of a housing project of the same kind can only cover regular expenses and gain a tiny profit, this is an ordinary sales level; (3) when salesratio reaches merely $30 \%$, this is considered a failure despite the efforts. As we got the above three conclusions, we reconfirmed with the Delphi expert group. Therefore, we defined the scope of the sales-ratio in three levels: "good", "fair" and "poor". The fuzzy set of each criterion is shown in Table 1.

\subsection{Membership functions of Each Criterion}

A membership function characterizes a fuzzy linguistic term by giving its support value, i.e. the degree of membership. The membership value varies from 0 to 1 , representing none to full membership. Membership functions commonly used include triangular functions and bell-shaped functions [16]. The bell-shaped function which has a smoother rating converting curve appears to be closer to a decision-maker's logic; however, such a function requires more computational effort. As a result, in order to reduce the complexity of FLIS computations, we use bell-shaped functions as output, but triangular functions as input. In addition, we have to determine the mean value and spread (or bell width); and the peak value and the width of the bottom of triangular functions. This study determines each criterion, in detail, according to its evaluation by an expert group. The final membership function is shown in Figure 8.

\subsection{IF-THEN rules and Logic Gate model}

As the description of section 4, there are four input criteria used in this research: "Design/regional environment", "Price/competitiveness", "Economic status/Policy" and "Agree-

Table 1. Definition of Input Criteria/Output Values

\begin{tabular}{|c|c|c|c|c|c|}
\hline Input Criteria & & & & Output & \\
\hline Criterion name & Abbr. & Value Range & Fuzzy set & Name & Fuzzy set \\
\hline \multirow{3}{*}{$\begin{array}{l}\text { Design/Regional } \\
\text { Environment }\end{array}$} & \multirow{3}{*}{$\mathrm{D}$} & \multirow{3}{*}{$0-100$} & Good & \multirow{12}{*}{ Sales-Ratio } & \\
\hline & & & Fair & & \\
\hline & & & Poor & & \\
\hline \multirow{3}{*}{ Agreement/Relationship } & \multirow{3}{*}{ A } & \multirow{3}{*}{$0-100$} & Good & & \\
\hline & & & Fair & & High \\
\hline & & & Poor & & \multirow{7}{*}{$\begin{array}{l}\text { Low } \\
\text { Value Range: } 0-100 \%\end{array}$} \\
\hline \multirow{3}{*}{ Price/Competitiveness } & \multirow{3}{*}{$\mathrm{P}$} & \multirow{3}{*}{$0-10$} & High & & \\
\hline & & & Moderate & & \\
\hline & & & Low & & \\
\hline \multirow{3}{*}{$\begin{array}{l}\text { Economic Status/ } \\
\text { Policy coherence }\end{array}$} & \multirow{3}{*}{$\mathrm{E}$} & \multirow{3}{*}{$0-15$} & Hot & & \\
\hline & & & Common & & \\
\hline & & & Blue & & \\
\hline
\end{tabular}



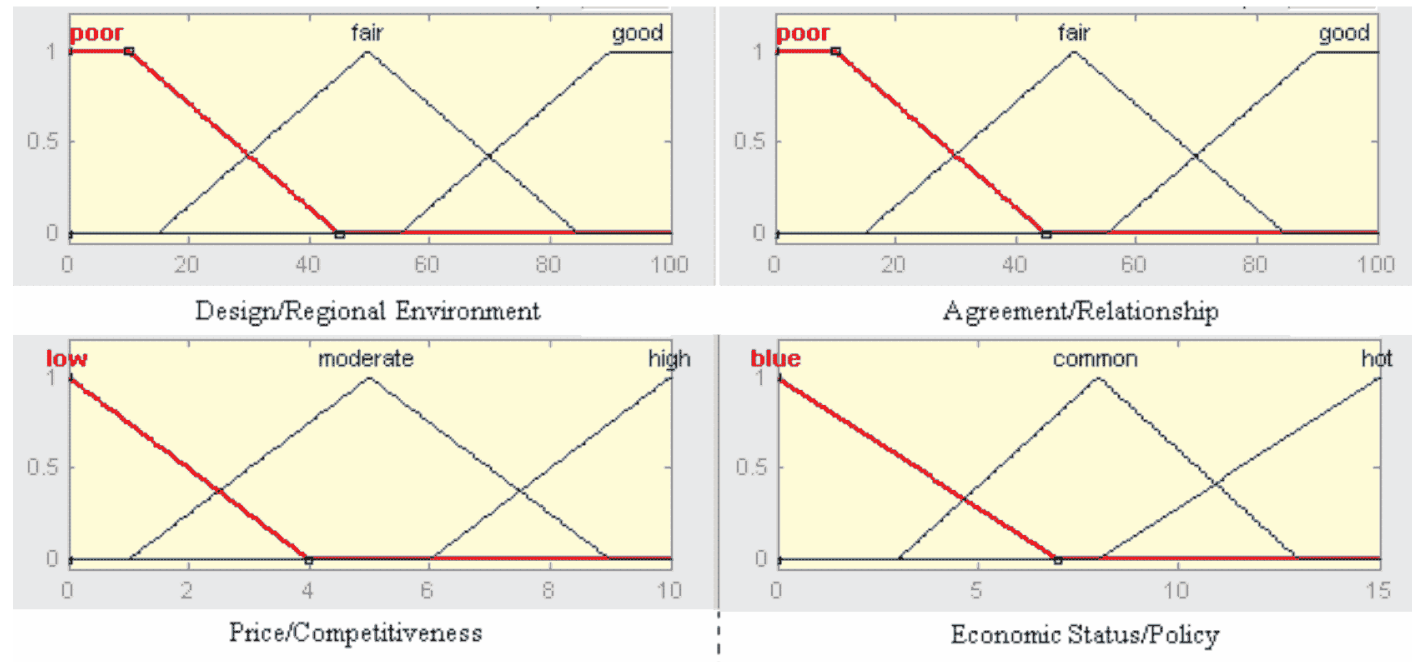

Agreement/Relationship

Input Criteria

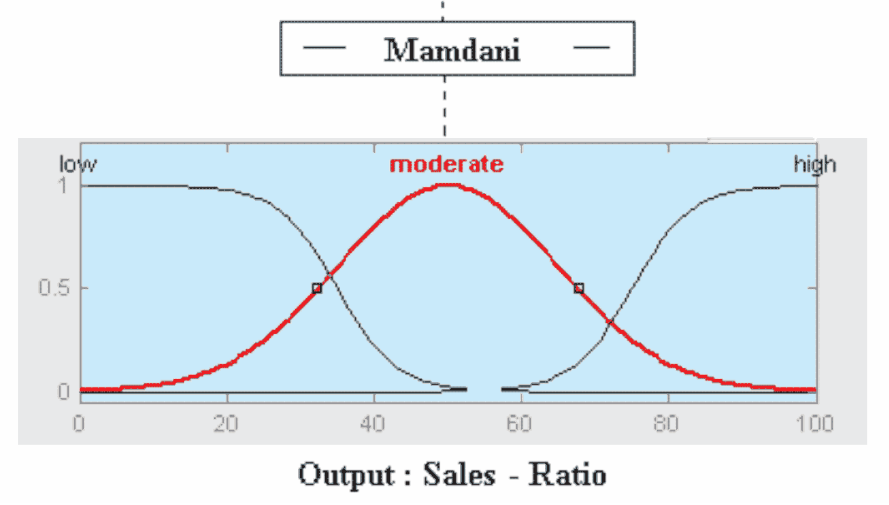

Input Criteria

Figure 8. The Membership Function of Input and Output

ment/relationship". Based on a conclusive agreement by the interviewed professionals, the rules affecting the values of sales-ratios should be grouped into four rule bases. The rule base descriptions are as follows:

1. If "Economic status/Policy coherence" is low: (1) "Design/Regional environment", "Price/ competitiveness" and "Agreement/relationship" are high, then sales-ratio will be moderate; (2) for other arrangements, the sales-ratio will be low.

2. When "Economic status/Policy coherence" is moderate, and "Design/regional environment", "Price/competitiveness" and "Agreement/relationship" are either high or moderate, thus if all other criteria are high, then a high sales-ratio can be expected; otherwise, the expected sales-ratio will be moderate.

3. While "Economic status/Policy coherence" is high: (1) If "Design/regional environment," "Price/competitiveness" and "Agreement/relationship" are high, or any of the criteria are moderate, then a high sales ratio can be expected; (2) Suppose more than two criteria are moderate or "Design/Regional environment" and "Agreement/relationship" are high and "Price/competitiveness" is low, then the expected sales ratio will be moderate.

4. If either "Design/Regional environment" or "Agreement/relationship" is low, then expected sales-ratio will be low.

In the aforementioned text, we gave ex- 
amples that showed AND/OR Logic Gate Models are the same as traditional if-then structures (AND/OR operators), but we apply the Logic Gate Model in our study because it reveals clearly the relationship between professional information and if-then rules and at the same time it is easy to analyze, examine ifthen rules influence upon model-building process and maintenance afterwards.

We use D, P, E and A to represent "Design/ regional environment", "Price/competitiveness", "Economic status/Policy" and "Agreement/relationship" respectively. Meanwhile, $\mathrm{A}_{\mathrm{H}}, \mathrm{A}_{\mathrm{M}}$ and
$\mathrm{A}_{\mathrm{L}}$ are used to represent criterion's A three membership functions: High, Moderate, Low (and D, P and E criterion likewise). After that, we apply the Logic Gate Model to represent the knowledge rules expressed by ordinary linguistic terms, and use Boolean algebra to compute the relationship between input and output as following.

Expert Rule 1. Logic Gate Model as Figure 9.(a), when Economic status/Policy coherence is low $\left(\mathrm{E}_{\mathrm{L}}\right), \mathrm{A}, \mathrm{D}, \mathrm{P}$ criterion might be High, Moderate or Low, but only when all three are High, is output Moderate, as for other sce-

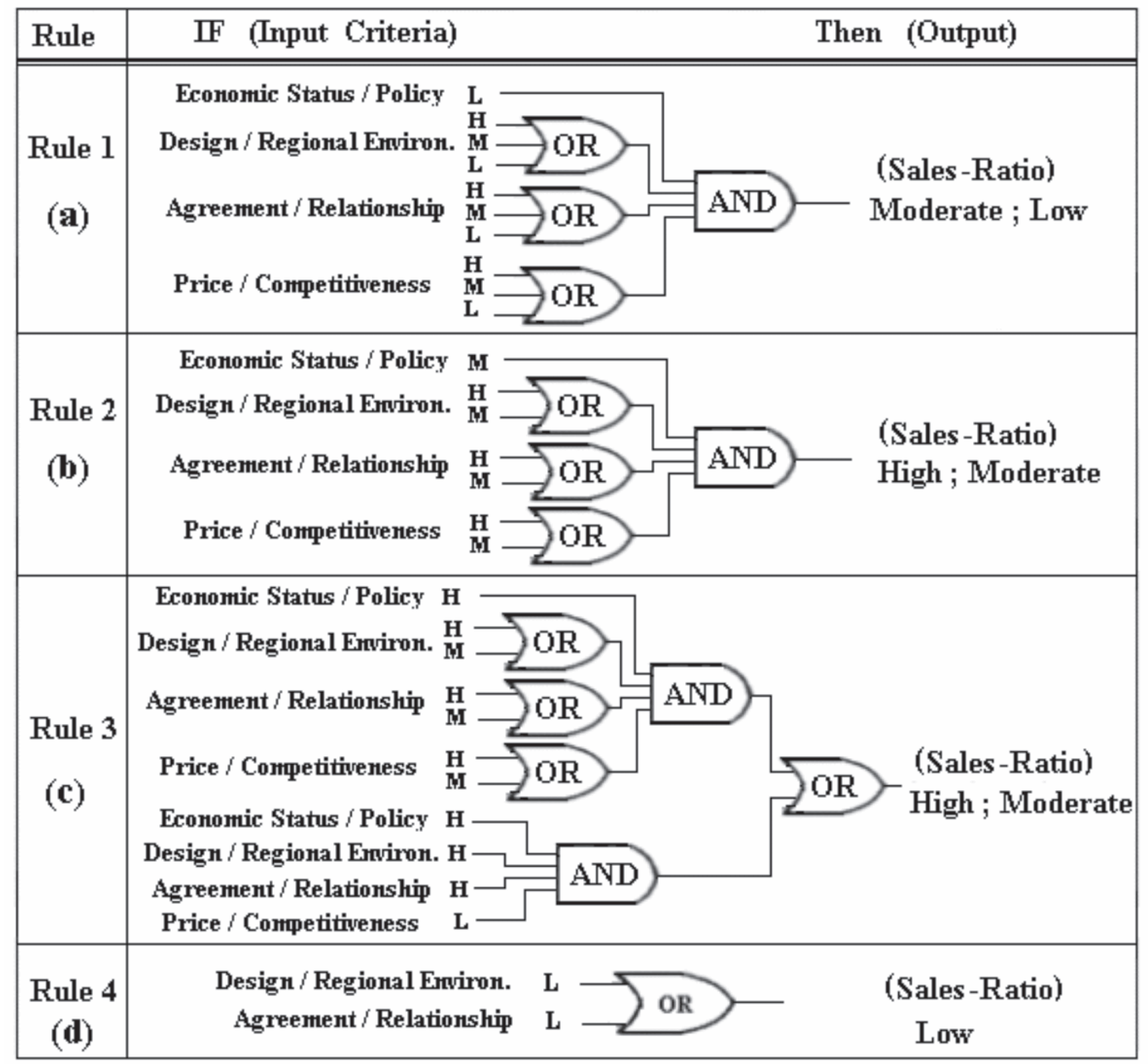

Figure 9. The Logic Gate Model of Rules 
narios, they lead to output Low. We use Boolean algebra to transform expert information into the followings rules:

Output $=$

$\mathrm{E}_{\mathrm{L}}\left(\mathrm{D}_{\mathrm{H}}+\mathrm{D}_{\mathrm{M}}+\mathrm{D}_{\mathrm{L}}\right)\left(\mathrm{A}_{\mathrm{H}}+\mathrm{A}_{\mathrm{M}}+\mathrm{A}_{\mathrm{L}}\right)\left(\mathrm{P}_{\mathrm{H}}+\mathrm{P}_{\mathrm{M}}+\mathrm{P}_{\mathrm{L}}\right)$

$=\mathrm{E}_{\mathrm{L}} \mathrm{D}_{\mathrm{H}} \mathrm{A}_{\mathrm{H}} \mathrm{P}_{\mathrm{H}}+\mathrm{E}_{\mathrm{L}} \mathrm{D}_{\mathrm{H}} \mathrm{A}_{\mathrm{M}} \mathrm{P}_{\mathrm{H}}+\mathrm{E}_{\mathrm{L}} \mathrm{D}_{\mathrm{H}} \mathrm{A}_{\mathrm{L}} \mathrm{P}_{\mathrm{H}}+\mathrm{E}_{\mathrm{L}} \mathrm{D}_{\mathrm{H}} \mathrm{A}_{\mathrm{H}} \mathrm{P}_{\mathrm{M}}$ $+\mathrm{E}_{\mathrm{L}} \mathrm{D}_{\mathrm{H}} \mathrm{A}_{\mathrm{M}} \mathrm{P}_{\mathrm{M}}+\mathrm{E}_{\mathrm{L}} \mathrm{D}_{\mathrm{H}} \mathrm{A}_{\mathrm{L}} \mathrm{P}_{\mathrm{M}}+\mathrm{E}_{\mathrm{L}} \mathrm{D}_{\mathrm{H}} \mathrm{A}_{\mathrm{H}} \mathrm{P}_{\mathrm{L}}+\mathrm{E}_{\mathrm{L}} \mathrm{D}_{\mathrm{H}} \mathrm{A}_{\mathrm{M}} \mathrm{P}_{\mathrm{L}}$ $+\mathrm{E}_{\mathrm{L}} \mathrm{D}_{\mathrm{H}} \mathrm{A}_{\mathrm{L}} \mathrm{P}_{\mathrm{L}}+\mathrm{E}_{\mathrm{L}} \mathrm{D}_{\mathrm{M}} \mathrm{A}_{\mathrm{H}} \mathrm{P}_{\mathrm{H}}+\mathrm{E}_{\mathrm{L}} \mathrm{D}_{\mathrm{M}} \mathrm{A}_{\mathrm{M}} \mathrm{P}_{\mathrm{H}}$ $+\mathrm{E}_{\mathrm{L}} \mathrm{D}_{\mathrm{M}} \mathrm{A}_{\mathrm{H}} \mathrm{P}_{\mathrm{M}}+\mathrm{E}_{\mathrm{L}} \mathrm{D}_{\mathrm{M}} \mathrm{A}_{\mathrm{M}} \mathrm{P}_{\mathrm{M}^{+}}+\mathrm{E}_{\mathrm{L}} \mathrm{D}_{\mathrm{M}} \mathrm{A}_{\mathrm{L}} \mathrm{P}_{\mathrm{M}^{+}} \mathrm{E}_{\mathrm{L}} \mathrm{D}_{\mathrm{M}} \mathrm{A}_{\mathrm{H}} \mathrm{P}_{\mathrm{L}}$ $+\mathrm{E}_{\mathrm{L}} \mathrm{D}_{\mathrm{M}} \mathrm{A}_{\mathrm{M}} \mathrm{P}_{\mathrm{L}}+\mathrm{E}_{\mathrm{L}} \mathrm{D}_{\mathrm{M}} \mathrm{A}_{\mathrm{L}} \mathrm{P}_{\mathrm{L}}+\mathrm{E}_{\mathrm{L}} \mathrm{D}_{\mathrm{L}} \mathrm{A}_{\mathrm{H}} \mathrm{P}_{\mathrm{H}}+\mathrm{E}_{\mathrm{L}} \mathrm{D}_{\mathrm{L}} \mathrm{A}_{\mathrm{M}} \mathrm{P}_{\mathrm{H}}$ $+E_{L} D_{L} A_{L} P_{H}+E_{L} D_{L} A_{H} P_{M}+E_{L} D_{L} A_{M} P_{M}$ $+\mathrm{E}_{\mathrm{L}} \mathrm{D}_{\mathrm{L}} \mathrm{A}_{\mathrm{L}} \mathrm{P}_{\mathrm{M}}+\mathrm{E}_{\mathrm{L}} \mathrm{D}_{\mathrm{L}} \mathrm{A}_{\mathrm{H}} \mathrm{P}_{\mathrm{L}}+\mathrm{E}_{\mathrm{L}} \mathrm{D}_{\mathrm{L}} \mathrm{A}_{\mathrm{M}} \mathrm{P}_{\mathrm{L}}+\mathrm{E}_{\mathrm{L}} \mathrm{D}_{\mathrm{L}} \mathrm{A}_{\mathrm{L}} \mathrm{P}_{\mathrm{L}}$ (27 Scenarios)

The result of Rule 1 is 27 Scenarios of which only $\mathrm{E}_{\mathrm{L}} \mathrm{D}_{\mathrm{H}} \mathrm{A}_{\mathrm{H}} \mathrm{P}_{\mathrm{H}}$ Scenario yields moderate output all others yield low output Table 2 (Rule 1). Likewise, we can apply the Logic Gate Model and Boolean algebra to compute Expert's Rule 2, 3, and 4 to obtain the needed rules for FLIS.

Expert Rule 2. Logic Gate Model, as in Figure 9(b), the computation is as follows:

$$
\begin{aligned}
& \text { Output }=\mathrm{E}_{\mathrm{M}}\left(\mathrm{D}_{\mathrm{H}}+\mathrm{D}_{\mathrm{M}}\right)\left(\mathrm{A}_{\mathrm{H}^{+}} \mathrm{A}_{\mathrm{M}}\right)\left(\mathrm{P}_{\mathrm{H}^{+}} \mathrm{P}_{\mathrm{M}}\right) \\
& =\mathrm{E}_{\mathrm{M}} \mathrm{D}_{\mathrm{H}} \mathrm{A}_{\mathrm{H}} \mathrm{P}_{\mathrm{H}^{+}} \mathrm{E}_{\mathrm{M}} \mathrm{D}_{\mathrm{H}} \mathrm{A}_{\mathrm{M}} \mathrm{P}_{\mathrm{H}^{+}}+\mathrm{E}_{\mathrm{M}} \mathrm{D}_{\mathrm{H}} \mathrm{A}_{\mathrm{H}} \mathrm{P}_{\mathrm{M}} \\
& +\mathrm{E}_{\mathrm{M}} \mathrm{D}_{\mathrm{H}} \mathrm{A}_{\mathrm{M}} \mathrm{P}_{\mathrm{M}}+\mathrm{E}_{\mathrm{M}} \mathrm{D}_{\mathrm{M}} \mathrm{A}_{\mathrm{H}} \mathrm{P}_{\mathrm{H}}+\mathrm{E}_{\mathrm{M}} \mathrm{D}_{\mathrm{M}} \mathrm{A}_{\mathrm{M}} \mathrm{P}_{\mathrm{H}} \\
& +\mathrm{E}_{\mathrm{M}} \mathrm{D}_{\mathrm{M}} \mathrm{A}_{\mathrm{H}} \mathrm{P}_{\mathrm{M}}+\mathrm{E}_{\mathrm{M}} \mathrm{D}_{\mathrm{M}} \mathrm{A}_{\mathrm{M}} \mathrm{P}_{\mathrm{M}}
\end{aligned}
$$

Eight (8) Scenarios are derived from the Expert Rule 2, but only the $\mathrm{E}_{\mathrm{M}} \mathrm{D}_{\mathrm{H}} \mathrm{A}_{\mathrm{H}} \mathrm{P}_{\mathrm{H}}$ Scenario, produces high output. As above mentioned, the rules affecting the values of salesratios should be grouped into four rule bases. From rule 2, when $\mathrm{E}$ - moderate, and $\mathrm{D}$, and $\mathrm{A}$, and $\mathrm{P}$ are high, then a high sales-ratio can be expected; all others lead to moderate output. See Table 2 (Rule 2).

Expert Rule 3. Logic Gate Model as Figure 9.(c), the computation result is as below:

$$
\begin{aligned}
& \text { Output }=\mathrm{E}_{\mathrm{H}}\left(\mathrm{D}_{\mathrm{H}^{+}} \mathrm{D}_{\mathrm{M}}\right)\left(\mathrm{A}_{\mathrm{H}^{+}} \mathrm{A}_{\mathrm{M}}\right)\left(\mathrm{P}_{\mathrm{H}^{+}} \mathrm{P}_{\mathrm{M}}\right) \\
& +\mathrm{E}_{\mathrm{H}} \mathrm{D}_{\mathrm{H}} \mathrm{A}_{\mathrm{H}} \mathrm{P}_{\mathrm{L}}=\mathrm{E}_{\mathrm{H}} \mathrm{D}_{\mathrm{H}} \mathrm{A}_{\mathrm{H}} \mathrm{P}_{\mathrm{H}^{+}} \mathrm{E}_{\mathrm{H}} \mathrm{D}_{\mathrm{M}} \mathrm{A}_{\mathrm{H}} \mathrm{P}_{\mathrm{H}} \\
& +\mathrm{E}_{\mathrm{H}} \mathrm{D}_{\mathrm{H}} \mathrm{A}_{\mathrm{H}} \mathrm{P}_{\mathrm{M}^{+}} \mathrm{E}_{\mathrm{H}} \mathrm{D}_{\mathrm{H}} \mathrm{A}_{\mathrm{M}} \mathrm{P}_{\mathrm{H}}+\mathrm{E}_{\mathrm{H}} \mathrm{D}_{\mathrm{H}} \mathrm{A}_{\mathrm{M}} \mathrm{P}_{\mathrm{M}} \\
& +\mathrm{E}_{\mathrm{H}} \mathrm{D}_{\mathrm{M}} \mathrm{A}_{\mathrm{M}} \mathrm{P}_{\mathrm{H}^{+}} \mathrm{E}_{\mathrm{H}} \mathrm{D}_{\mathrm{M}} \mathrm{A}_{\mathrm{H}} \mathrm{P}_{\mathrm{M}^{+}} \mathrm{E}_{\mathrm{H}} \mathrm{D}_{\mathrm{M}} \mathrm{A}_{\mathrm{M}} \mathrm{P}_{\mathrm{M}} \\
& +\mathrm{E}_{\mathrm{H}} \mathrm{D}_{\mathrm{H}} \mathrm{A}_{\mathrm{H}} \mathrm{P}_{\mathrm{L}} \quad \text { (9 Scenarios) }
\end{aligned}
$$

Expert Rule 3 produces 9 Scenarios, $\mathrm{E}_{\mathrm{H}} \mathrm{D}_{\mathrm{H}} \mathrm{A}_{\mathrm{H}} \mathrm{P}_{\mathrm{H}}, \mathrm{E}_{\mathrm{H}} \mathrm{D}_{\mathrm{M}} \mathrm{A}_{\mathrm{H}} \mathrm{P}_{\mathrm{H}}, \mathrm{E}_{\mathrm{H}} \mathrm{D}_{\mathrm{H}} \mathrm{A}_{\mathrm{H}} \mathrm{P}_{\mathrm{M}}$, and $\mathrm{E}_{\mathrm{H}} \mathrm{D}_{\mathrm{H}} \mathrm{A}_{\mathrm{M}} \mathrm{P}_{\mathrm{H}}$ Scenarios; the other 5 Scenarios yield high output. $\mathrm{E}_{\mathrm{H}} \mathrm{D}_{\mathrm{H}} \mathrm{A}_{\mathrm{M}} \mathrm{P}_{\mathrm{M}}, \mathrm{E}_{\mathrm{H}} \mathrm{D}_{\mathrm{M}} \mathrm{A}_{\mathrm{M}} \mathrm{P}_{\mathrm{H}}$, $\mathrm{E}_{\mathrm{H}} \mathrm{D}_{\mathrm{M}} \mathrm{A}_{\mathrm{H}} \mathrm{P}_{\mathrm{M}}, \mathrm{E}_{\mathrm{H}} \mathrm{D}_{\mathrm{M}} \mathrm{A}_{\mathrm{M}} \mathrm{P}_{\mathrm{M}}$, and $\mathrm{E}_{\mathrm{H}} \mathrm{D}_{\mathrm{H}} \mathrm{A}_{\mathrm{H}} \mathrm{P}_{\mathrm{L}}$, all lead to moderate output. See Table 2 (Rule 3 ).

Expert Rule 4. Logic Gate Model as Figure $9(\mathrm{~d})$, the results are:

Output $(\mathrm{LOW})=\mathrm{DL}+\mathrm{AL},(+:$ means" OR" $)$; as long as Design/Regional Environment or Agreement/Relationship is low, the expected sales ratio is low. See Table 2 (Rule 4).

The results of the above computations show that there are 27 'AND' rules for Expert Rule 1; 8 'AND' rules for Expert Rule 2; 9 'AND' rules for Experts' Rule 3 and 1 'OR' rule for Expert Rule 4; there are in total 45 rules after the above process, 44 of which use an 'AND' operator, and one uses an 'OR' operator. All the IF-THEN rules are as in Table 2. In simple terms, the rules such as these function in a way similar to the use of experiential knowledge by a human brain. As soon as FLIS establishes an inference rule, the program can carry out the functions of inference pertaining to that particular rule. FLIS can compute, automatically, the estimated sales ratio once the decision-makers input the conclusion of evaluation of each criterion.

\section{APPLICATION}

\subsection{Sales-ratio evaluation}

This study transforms all the input evaluation values of criteria through Fuzzy system output to be the sales ratio of a Housing project. The value of each input criterion represents a contribution to the overall project attraction to the purchasers of the housing units being offered. The higher the value, the more appealing the candidate development project, and vice versa.

The value is decided according to the influence of each input. For example: in the case of two 'Good' criteria and two 'Poor' criteria, the sales-ratio may be better than in cases where 
Table 2. Fuzzy IF-THEN Rule Base

\begin{tabular}{|c|c|c|c|c|c|c|c|c|c|c|c|}
\hline $\begin{array}{l}\text { Expert } \\
\text { Knowledge }\end{array}$ & Code & & $\begin{array}{l}\text { Design/Regional } \\
\text { Enviro. is }\end{array}$ & & $\begin{array}{l}\text { Agreement/ } \\
\text { Relat. is }\end{array}$ & & $\begin{array}{l}\text { Price/ } \\
\text { Competit. is }\end{array}$ & & $\begin{array}{l}\text { Economic } \\
\text { Status is }\end{array}$ & & Sales-Ratio is \\
\hline Rule 1 & 1 & IF & Good & $\wedge$ & Good & $\wedge$ & High & $\wedge$ & Blue & THEN & Moderate \\
\hline \multirow[t]{26}{*}{ Figure 9(a) } & 2 & IF & Good & $\wedge$ & Fair & $\wedge$ & High & $\wedge$ & Blue & THEN & Low \\
\hline & 3 & IF & Good & $\wedge$ & Poor & $\wedge$ & High & $\wedge$ & Blue & THEN & Low \\
\hline & 4 & IF & Good & $\wedge$ & Good & $\wedge$ & Moderate & $\wedge$ & Blue & THEN & Low \\
\hline & 5 & IF & Good & $\wedge$ & Fair & $\wedge$ & Moderate & $\wedge$ & Blue & THEN & Low \\
\hline & 6 & IF & Good & $\wedge$ & Poor & $\wedge$ & Moderate & $\wedge$ & Blue & THEN & Low \\
\hline & 7 & IF & Good & $\wedge$ & Good & $\wedge$ & Low & $\wedge$ & Blue & THEN & Low \\
\hline & 8 & IF & Good & $\wedge$ & Fair & $\wedge$ & Low & $\wedge$ & Blue & THEN & Low \\
\hline & 9 & IF & Good & $\wedge$ & Poor & $\wedge$ & Low & $\wedge$ & Blue & THEN & Low \\
\hline & 10 & IF & Fair & $\wedge$ & Good & $\wedge$ & High & $\wedge$ & Blue & THEN & Low \\
\hline & 11 & IF & Fair & $\wedge$ & Fair & $\wedge$ & High & $\wedge$ & Blue & THEN & Low \\
\hline & 12 & IF & Fair & $\wedge$ & Poor & $\wedge$ & High & $\wedge$ & Blue & THEN & Low \\
\hline & 13 & IF & Fair & $\wedge$ & Good & $\wedge$ & Moderate & $\wedge$ & Blue & THEN & Low \\
\hline & 14 & IF & Fair & $\wedge$ & Fair & $\wedge$ & Moderate & $\wedge$ & Blue & THEN & Low \\
\hline & 15 & IF & Fair & $\wedge$ & Poor & $\wedge$ & Moderate & $\wedge$ & Blue & THEN & Low \\
\hline & 16 & IF & Fair & $\wedge$ & Good & $\wedge$ & Low & $\wedge$ & Blue & THEN & Low \\
\hline & 17 & IF & Fair & $\wedge$ & Fair & $\wedge$ & Low & $\wedge$ & Blue & THEN & Low \\
\hline & 18 & IF & Fair & $\wedge$ & Poor & $\wedge$ & Low & $\wedge$ & Blue & THEN & Low \\
\hline & 19 & IF & Poor & $\wedge$ & Good & $\wedge$ & High & $\wedge$ & Blue & THEN & Low \\
\hline & 20 & IF & Poor & $\wedge$ & Fair & $\wedge$ & High & $\wedge$ & Blue & THEN & Low \\
\hline & 21 & IF & Poor & $\wedge$ & Poor & $\wedge$ & High & $\wedge$ & Blue & THEN & Low \\
\hline & 22 & IF & Poor & $\wedge$ & Good & $\wedge$ & Moderate & $\wedge$ & Blue & THEN & Low \\
\hline & 23 & IF & Poor & $\wedge$ & Fair & $\wedge$ & Moderate & $\wedge$ & Blue & THEN & Low \\
\hline & 24 & IF & Poor & $\wedge$ & Poor & $\wedge$ & Moderate & $\wedge$ & Blue & THEN & Low \\
\hline & 25 & IF & Poor & $\wedge$ & Good & $\wedge$ & Low & $\wedge$ & Blue & THEN & Low \\
\hline & 26 & IF & Poor & $\wedge$ & Fair & $\wedge$ & Low & $\wedge$ & Blue & THEN & Low \\
\hline & 27 & IF & Poor & $\wedge$ & Poor & $\wedge$ & Low & $\wedge$ & Blue & THEN & Low \\
\hline Rule 2 & 28 & IF & Good & $\wedge$ & Good & $\wedge$ & High & $\wedge$ & Common & THEN & High \\
\hline \multirow[t]{7}{*}{ Figure 9(b) } & 29 & IF & Good & $\wedge$ & Fair & $\wedge$ & High & $\wedge$ & Common & THEN & Moderate \\
\hline & 30 & IF & Good & $\wedge$ & Good & $\wedge$ & Moderate & $\wedge$ & Common & THEN & Moderate \\
\hline & 31 & IF & Good & $\wedge$ & Fair & $\wedge$ & Moderate & $\wedge$ & Common & THEN & Moderate \\
\hline & 32 & IF & Fair & $\wedge$ & Good & $\wedge$ & High & $\wedge$ & Common & THEN & Moderate \\
\hline & 33 & IF & Fair & $\wedge$ & Fair & $\wedge$ & High & $\wedge$ & Common & THEN & Moderate \\
\hline & 34 & IF & Fair & $\wedge$ & Good & $\wedge$ & Moderate & $\wedge$ & Common & THEN & Moderate \\
\hline & 35 & IF & Fair & $\wedge$ & Fair & $\wedge$ & Moderate & $\wedge$ & Common & THEN & Moderate \\
\hline Rule 3 & 36 & IF & Good & $\wedge$ & Good & $\wedge$ & High & $\wedge$ & Hot & THEN & High \\
\hline \multirow[t]{8}{*}{ Figure 9(c) } & 37 & IF & Fair & $\wedge$ & Good & $\wedge$ & High & $\wedge$ & Hot & THEN & High \\
\hline & 38 & IF & Good & $\wedge$ & Good & $\wedge$ & Moderate & $\wedge$ & Hot & THEN & High \\
\hline & 39 & IF & Good & $\wedge$ & Fair & $\wedge$ & High & $\wedge$ & Hot & THEN & High \\
\hline & 40 & IF & Good & $\wedge$ & Fair & $\wedge$ & Moderate & $\wedge$ & Hot & THEN & Moderate \\
\hline & 41 & IF & Fair & $\wedge$ & Fair & $\wedge$ & High & $\wedge$ & Hot & THEN & Moderate \\
\hline & 42 & IF & Fair & $\wedge$ & Good & $\wedge$ & Moderate & $\wedge$ & Hot & THEN & Moderate \\
\hline & 43 & IF & Fair & $\wedge$ & Fair & $\wedge$ & Moderate & $\wedge$ & Hot & THEN & Moderate \\
\hline & 44 & IF & Good & $\wedge$ & Good & $\wedge$ & Low & $\wedge$ & Hot & THEN & Moderate \\
\hline $\begin{array}{l}\text { Rule } 4 \\
\text { Figure 9(d) }\end{array}$ & 45 & IF & Poor & OR & Poor & & ---- & & ---- & THEN & Low \\
\hline Remarks & High & G & Hot; Mode & rate & Fair & mor & n; Low & oor & Blue & & \\
\hline
\end{tabular}


all four criteria are only 'Fair.' Also, since the overall economic situation in an area in question plays an influential role, if the economy is 'hot', even with only one "Good" criterion, the sales-ratio may still be better than others that got other 'Good' criteria conditions and this is the unique feature of FLIS. Figure 10 displays the complex relationships involving of the sales ratio, including influences of each criterion. This complexity has traditionally puzzled traditional owners when they were evaluating the sales rates. In business practice, even an experienced decision-maker may still be unable to make an accurate judgment about how each criterion, in qualitative and quantitative terms, affects the sales rate. FLIS allows a user to automate the computation of sales ratios based on the standardized inputs of parameters of interest, thus aiding in sound decision making related to investment in residential construc- tion projects even by relatively inexperienced investors.

\subsection{Case study 1}

We employed FLIS to evaluate the housing sales ratio in the Chinese cities of Shanghai, Chung-Shan and Chu-hai to contrast these markets and as a practical demonstration of the usefulness of the proposed model.

There are two sales patterns in the domain area; the first pattern is that consumers buy roughcast housing and then appoint a fix-up/ furnishing agent themselves to complete water, electricity, tile, kitchen and sanitary facilities, which we call 'traditional-shop'. The second pattern is roughcast housing with all interiors completed, a product of this kind is called 'one-stop-shop'. Since the above three listed cities share similar 'Agreement/ relationship', 'Design/Regional environment' and 'Eco-

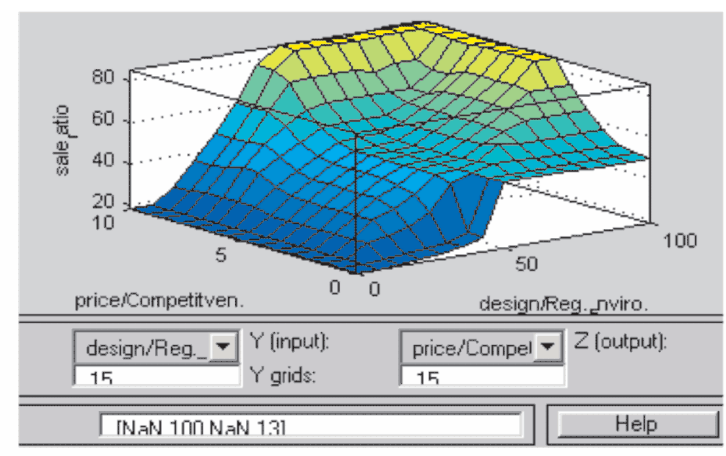

(a) Extremely Hot

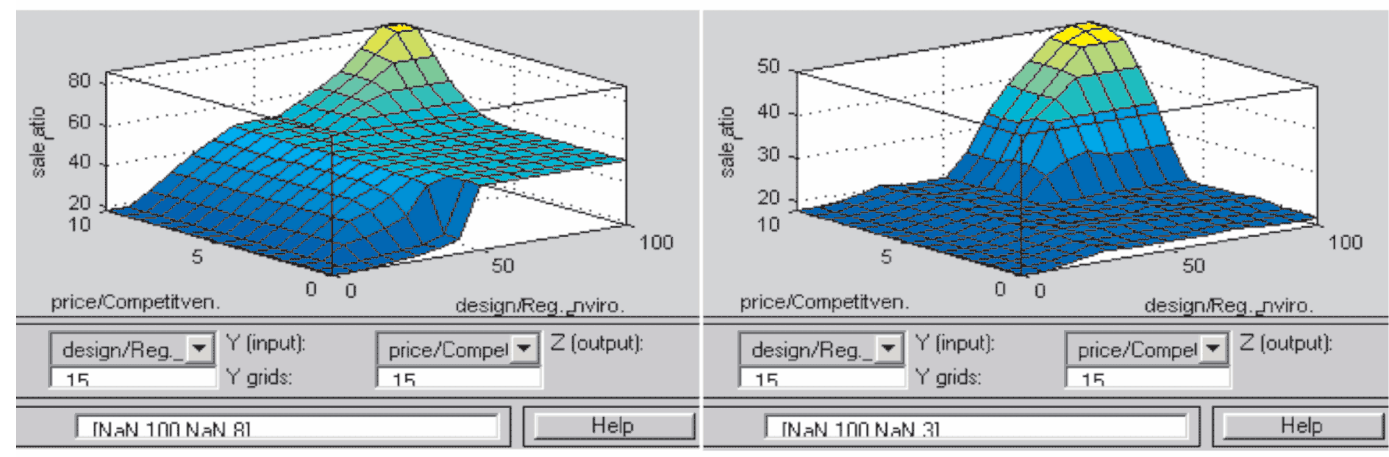

(b) Common

(c) Extremely Blue

Figure 10. Variation Relationship Between Sales-Ratio and Influential Factors Under Different Economic Conditions 
nomic status/policy' conditions, the consumers of the domain area produce. Therefore, most likely the 'Price/Competitiveness' criterion has more impact on the sales ratio (refer to Table 3). Taking the variation of 'Price/competitiveness' to check the relationship between 'traditional-shop' and 'one-stop-shop', and we recognize that 'traditional-shop' products have to offer higher discounts to customers in order to have the same high sales ratio as 'one-stopshop'. As a result, a certain amount of profit will be sacrificed (Figure 11). Our model predicts that there will be $50-86 \%$ sales ratios for various sales prices and they are quite close to the real sales ratios of the housing projects, which were in reality between $50-85 \%$.

There is rising demand from Chinese customers for stylish housing; the phenomenon reminds of one of Bennett's [3] descriptions of the Japanese society of some 20 years ago. At that time, due to the accumulation of considerable fortunes, demand for high quality fashionable housing was growing. In response to this demand, five large Japanese general contractors established architectural design departments in their organizations particularly to undertake investigation of brand-new designs and high-tech construction materials, while investing in quality housing projects which customers demand. They also hired architects from Western countries to raise the quality of their designs. Based on Figure 11 displaying 'onestop-shop' relationships between price estimate and sales ratios, one can see that 'one-stop-shop' does not need to rely on price cuts to achieve good sales-ratios; indeed it shows a big discrepancy from the sales of 'traditional-shop'. The result indicates clearly that housing, demanded by customers in large cities, should be full-furnished and ready for habitation. Even though the Chinese roughcast housing construction sector at present is unlike its equivalent in the developed countries, engineering is similarly handled by interior furnishing/design companies. The survey shows that the best method to raise the future sales-ratio is to engage in chang-

Table 3. Shanghai's, ChungShan's, and Chuhai's Input Values

\begin{tabular}{|c|c|c|c|c|c|}
\hline Regional & Criterion & Evaluation method & $\begin{array}{l}\text { Constructor/ads } \\
\text { agent }(30)\end{array}$ & $\begin{array}{l}\text { The masses } \\
(70)\end{array}$ & System input value \\
\hline \multirow[t]{5}{*}{ Shanghai } & \multirow{2}{*}{$\begin{array}{l}\text { Design/Regional } \\
\text { Environment }\end{array}$} & \multirow[t]{2}{*}{ Questionnaire survey } & \multirow[t]{2}{*}{86} & \multirow[t]{2}{*}{88} & 87 \\
\hline & & & & & 45 (Rough) \\
\hline & Agreement/ Relationship & Select option & \multirow[t]{2}{*}{ Good } & \multirow[t]{2}{*}{ Good } & Good \\
\hline & Price/Competitiveness & Select option & & & Select option $(0 \% \sim 10 \%)$ \\
\hline & $\begin{array}{l}\text { Economic Status/Policy } \\
\text { coherence }\end{array}$ & $\begin{array}{l}\text { Chinese annual } \\
\text { economic growth rate }\end{array}$ & Hot & Hot & Hot \\
\hline \multirow[t]{5}{*}{ ChungShan } & \multirow{2}{*}{$\begin{array}{l}\text { Design/Regional } \\
\text { Environment }\end{array}$} & \multirow[t]{2}{*}{ Questionnaire survey } & \multirow[t]{2}{*}{84} & \multirow[t]{2}{*}{89} & 88 \\
\hline & & & & & 55 (Rough) \\
\hline & Agreement/ Relationship & Select option & \multirow[t]{2}{*}{ Good } & \multirow[t]{2}{*}{ Good } & Good \\
\hline & Price/Competitiveness & Select option & & & Select option $(0 \% \sim 10 \%)$ \\
\hline & $\begin{array}{l}\text { Economic Status/Policy } \\
\text { coherence }\end{array}$ & $\begin{array}{l}\text { Chinese annual } \\
\text { economic growth rate }\end{array}$ & Hot & Hot & Hot \\
\hline \multirow[t]{5}{*}{ Chuhai } & \multirow{2}{*}{$\begin{array}{l}\text { Design/Regional } \\
\text { Environment }\end{array}$} & \multirow[t]{2}{*}{ Questionnaire survey } & \multirow[t]{2}{*}{92} & \multirow[t]{2}{*}{90} & 91 \\
\hline & & & & & 61 (Rough) \\
\hline & Agreement/ Relationship & Select option & \multirow[t]{2}{*}{ Good } & \multirow[t]{2}{*}{ Good } & Good \\
\hline & Price/Competitiveness & Select option & & & Select option $(0 \% \sim 10 \%)$ \\
\hline & $\begin{array}{l}\text { Economic Status/Policy } \\
\text { coherence }\end{array}$ & $\begin{array}{l}\text { Chinese annual } \\
\text { economic growth rate }\end{array}$ & Hot & Hot & Hot \\
\hline
\end{tabular}



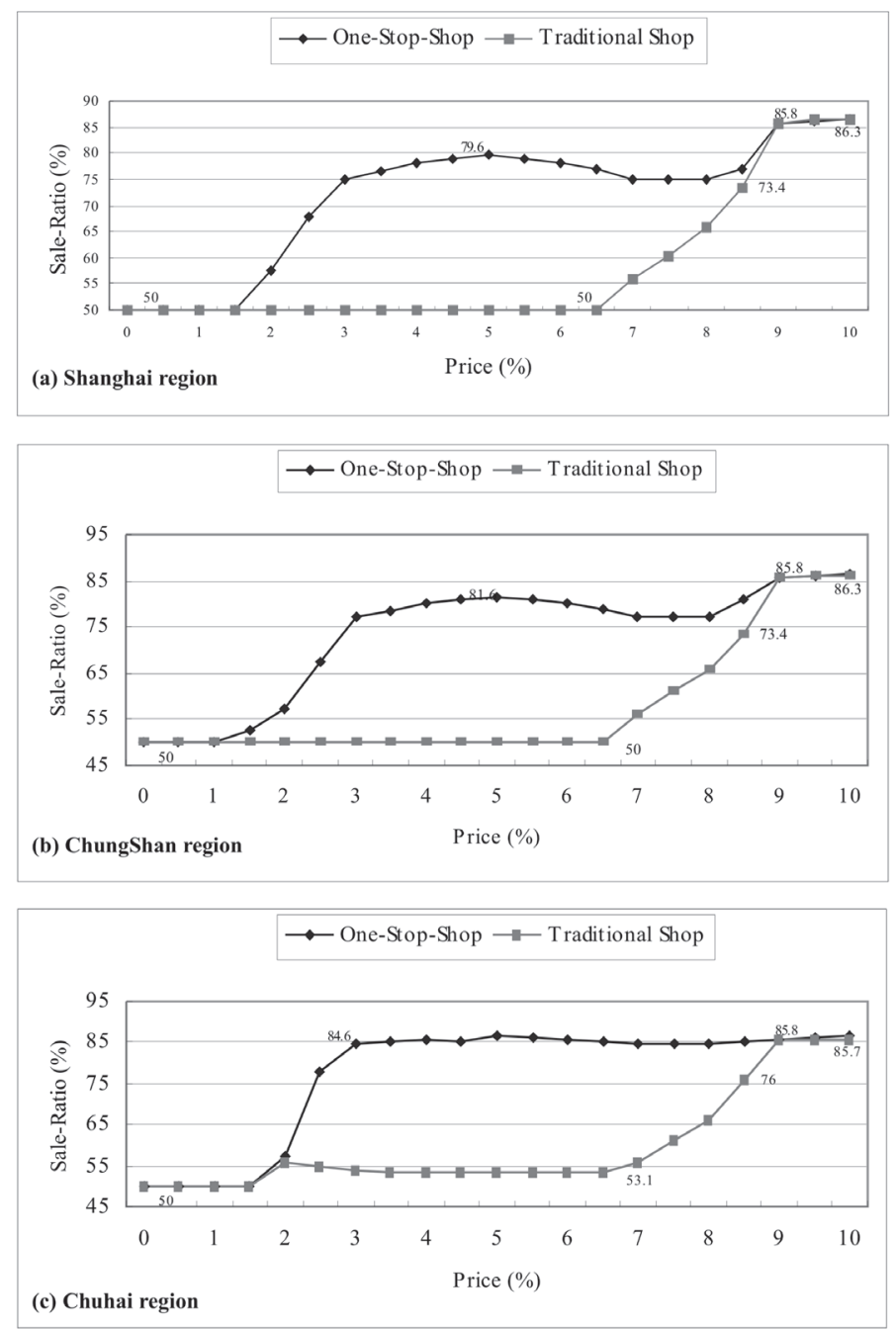

Figure 11. Product Plan Strategy and Sensitivity Analysis of Price Orientation

ing the bond between the supply chain of roughcast housing construction and customers, and to join roughcast housing with interior fix-up/ furnishing. The adjusted relationship between the supply chain of housing construction and its customers is shown in Figure 12.

\subsection{Case study 2}

The multi-unit residential project is located in an exclusive district of Chu-hai, all of the evaluation criteria described previously carry a value of 'good' except 'Plan/design'. The de- veloper went through a bankruptcy due to a poor sales ratio and a new developer took over the whole project. Even though the new developer views the project as high class, yet the sales ratio still is only about $40 \%$. Once again, we use the proposed model to analyze this case; and first on the fuzzy scale, we grade 40 on design criterion because it cannot meet customers' demand, but full scores for other criteria. Using FLIS, we obtained an estimated sales ratio of $43 \%$ and this result is similar to the actual ratio experienced by the developer in this high risk project. 


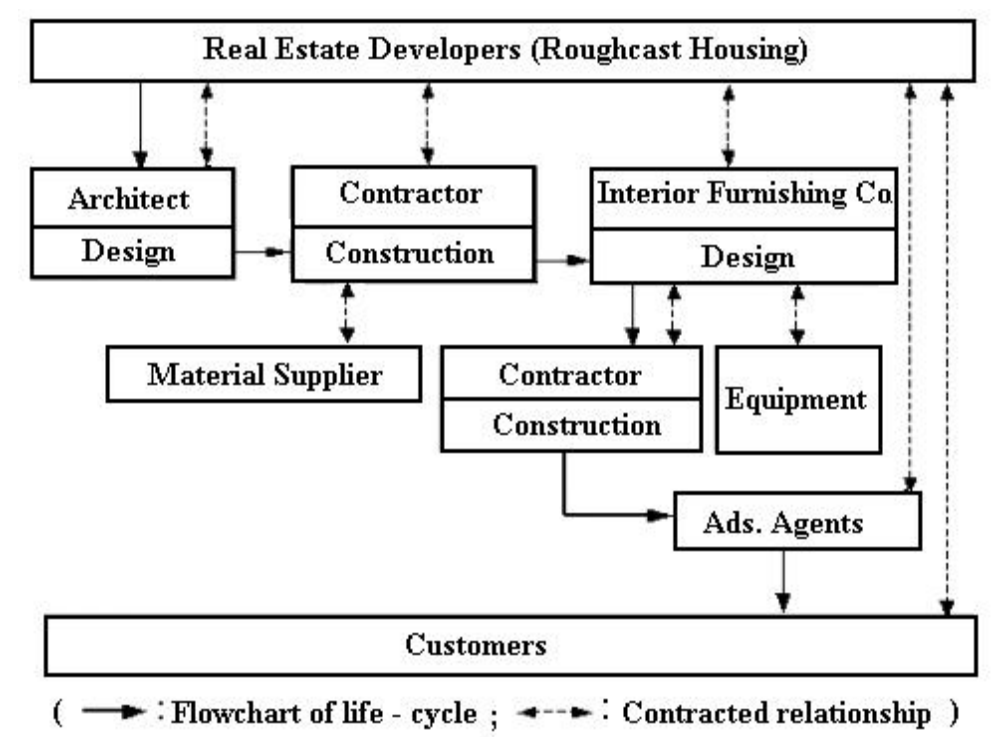

Figure 12. Customers' Demand for Stylish Housing Changes The Bond Between Supply Chain of Roughcast Housing Construction and Customers

\section{CONCLUSION}

The value of this research is based on its contribution to the creation of a structured evaluation mechanism facilitating a decisionmaking process for residential construction investment decisions based on rational judgment. Inconsistent or purely subjective decision-making can be avoided. We contrasted carefully the sales ratio estimated by FLIS with the actual results of the Chinese project. Only a 3\% discrepancy between these results was detected which proves the value of the developed model for application in business decision making. Based on the results of sensitivity analysis, it is suggested that the housing investors in the future are inevitable to engage in reorganizing the bond between the supply chain of housing construction and customers, such as: mergers between contractors and interior fix-up/furnishing companies; or mergers between real estate developers and interior fix-up/furnishing companies because only a construction structure of this kind is able to cater to customers' demand for fashionable housing and raise the product quality and the company's competitive position. Another contribution of this study is the use of the Logic Gate Model for transforming experts' knowledge, expressed by natural linguistic terms, into fuzzy inference models. In comparison with traditional 'if-then' structures, the logic gate model can present a more comprehensible process of establishing 'if-then' rules and can facilitate analysis, reduce error and help maintenance afterwards. With a very large number of decision input criteria, FLIS offers considerable advantages of its practical applications by human decision makers in housing market investment decisions.

\section{REFERENCES}

[1] H. E. Altas, Spatial adaptability and flexibility as parameters of user satisfaction for quality housing, Building and Environment, 33, 1998, p. 315-323.

[2] B. J. Baffoe, The dynamic impact of macroeconomic aggregates on housing price and stock of houses: a national and regional analysis, 
Journal of Real Estate Finance and Economics, 17(2), 1998, p. 179-197.

[3] J. Bennett, Japans building industry: the new model, Construction Management and Economics, 11, 1993, p. 3-17.

[4] L. W. Bing, L. K. R. Tiong, Risk management model for international construction joint ventures, Journal of Construction Engineering and Management, ASCE, 125(5), 1999, p. 377-384.

[5] R. Bon, D. Crosthwaite, The future of international construction: some results of 1992-1999 surveys, Building Research and Information, 29(3), 2001, p. 242-247.

[6] L. C. Chao, M. J. Skibniewski, Fuzzy logic for evaluating new construction technology, Journal of Construction Engineering and Management, ASCE, 124(4), 1998, p. 297-304.

[7] L. Grebler, The inflation of housing price, its extent, cause and consequences, Lexington Books, 1979.

[8] C. H. Ko, M. Y. Cheng, Hybrid use of AI techniques in developing construction management tools, Automation in Construction, 12, 2003, p. 271-281.

[9] L. Kornelius, J. W. F. Wamelink, The Virtual Corporation: learning from construction, Supply Chain Management, 3(4), 1998, p. 193-202.

[10] The National Bureau of Statistics of China, Yearbook 2001; http://210.72.32.6/cgi-bin/ bigate.cgi/b/g/g/http@210.72.32.26/yearbook2001/indexC.htm

[11] The National Bureau of Statistics of China, Yearbook 2002; http://www.stats.gov.cn/tjdt/ gjtjjdt/t20050225_402231580.htm

[12] J. G. Nillis, J. A. Longbotton, An empirical analysis of the determination of house prices in the United Kingdom, Urban Studies, University of Glasgow, 1981.
[13] A. Njoh, A client-oriented model for evaluating urban housing services in developing countries, Socio-Econ. Planning Science, 32(2), 1998, p. 139-153.

[14] A. Ozsoy, N. E. Altas, V. Ok and G. Pulat, Quality assessment model for housing: a case study on outdoor spaces in Istanbul, Habitat Intl., 20, 1996, p. 163-173.

[15] L. Y. Shen, W. C. G. Wu and S. K. C. Ng, Risk assessment for construction joint ventures in China, Journal of Construction Engineering and Management, ASCE, 127(1), 2001, p. 7681.

[16] W. D. Yu, M. J. Skibniewski, A neuro-fuzzy computational approach to constructability knowledge acquisition for construction technology evaluation, Automation in Construction, 8, 1999, p. 539-552.

[17] W. D. Yu, M. J. Skibniewski, Quantitative constructability analysis with a neuro-fuzzy knowledge-based multi-criterion decision support system, Automation in Construction, 8, 1999, p. 553-565.

[18] L. A. Zadeh, Fuzzy sets, Information and Control, 8(3), 1965, p. 338-353.

[19] M. M. Ziara, B. M. Ayyub, Decision analysis for housing-project development, Journal of Urban Planning and Development, ASCE, 125(2), 1999, p. 68-85.

[20] E. Ziglio, M. Adler, Gazing into the Oracle: The Delphi Method and its Application to Social Policy and Public Health, London: Jessica Kingsley, 1996, p. 1-33.

[21] H. J. Zimmermann, Fuzzy sets, decision making and expert systems, Kluwer Academic Publishers, 1987. 


\section{SANTRAUKA}

\section{BŪSTO STATYBOS KINIJOJE STRATEGIJŲ VERTINIMAS TAIKANT NEAPIBRĖŽTŲ AIBIŲ TEORIJĄ}

\section{Yeng-Horng PERNG, Sung-Lin HSUEH, Min-Ren YAN}

Kinijos būsto rinkai būdinga didelè paklausa ir didelis pelno potencialas. Tačiau užsienio investuotojai vis dar susiduria su didele rizika, nes nėra susipažinę su šios milžiniškos rinkos painiava. Šiame straipsnyje aptariama prekyba būstu Kinijos Liaudies Respublikoje, taikant neapibrěžtų aibių (Fuzzy Logic) ir Delfi metodus prognozuojamas prekybos efektyvumas Kinijos būsto rinkoje. Be to, darbe pristatomas loginiu elementu IR/ARBA pagrịstas modelis. Jis taikomas ekspertines žinias konvertuojant ị reikiamas sprendimų, susijusių su prekybos būstu sẻkmès prognozavimu, prièmimo taisykles. Loginio elemento modelis naudingas analizuojant taisyklę ,jei..., tai..”, taip pat stebint modelio kūrimo ir taisymo procesus bei prižiūrint modelị vèlesniais jo naudojimo etapais. Aprašytą modeli kaip kompiuterinị sprendimu paramos įranki gali taikyti užsienio investuotojai ir rangovai, iš anksto vertinantys verslo ịžengimo ị Kinijos būsto rinką galimybes. 